\title{
Gastroprotective activity of Annona muricata leaves against ethanol-induced gastric injury in rats via Hsp70/Bax involvement
}

This article was published in the following Dove Press journal:

Drug Design, Development and Therapy

28 October 2014

Number of times this article has been viewed

\author{
Soheil Zorofchian \\ Moghadamtousi' \\ Elham Rouhollahi \\ Hamed Karimian ${ }^{2}$ \\ Mehran Fadaeinasab ${ }^{3}$ \\ Mahmood Ameen Abdulla ${ }^{2}$ \\ Habsah Abdul Kadir' \\ 'Biomolecular Research Group, \\ Biochemistry Program, Institute of \\ Biological Sciences, Faculty of Science, \\ ${ }^{2}$ Department of Biomedical Science, \\ Faculty of Medicine, ${ }^{3}$ Department \\ of Chemistry, Faculty of Science, \\ University of Malaya, Kuala Lumpur, \\ Malaysia
}

\begin{abstract}
The popular fruit tree of Annona muricata L. (Annonaceae), known as soursop and graviola, is a widely distributed plant in Central and South America and tropical countries. Leaves of $A$. muricata have been reported to possess antioxidant and anti-inflammatory activities. In this study, the gastroprotective effects of ethyl acetate extract of $A$. muricata leaves (EEAM) were investigated against ethanol-induced gastric injury models in rats. The acute toxicity test of EEAM in rats, carried out in two doses of $1 \mathrm{~g} / \mathrm{kg}$ and $2 \mathrm{~g} / \mathrm{kg}$, showed the safety of this plant, even at the highest dose of $2 \mathrm{~g} / \mathrm{kg}$. The antiulcer study in rats (five groups, $\mathrm{n}=6$ ) was performed with two doses of EEAM $(200 \mathrm{mg} / \mathrm{kg}$ and $400 \mathrm{mg} / \mathrm{kg})$ and with omeprazole $(20 \mathrm{mg} / \mathrm{kg})$, as a standard antiulcer drug. Gross and histological features showed the antiulcerogenic characterizations of EEAM. There was significant suppression on the ulcer lesion index of rats pretreated with EEAM, which was comparable to the omeprazole effect in the omeprazole control group. Oral administration of EEAM to rats caused a significant increase in the level of nitric oxide and antioxidant activities, including catalase, glutathione, and superoxide dismutase associated with attenuation in gastric acidity, and compensatory effect on the loss of gastric wall mucus. In addition, pretreatment of rats with EEAM caused significant reduction in the level of malondialdehyde, as a marker for oxidative stress, associated with an increase in prostaglandin E2 activity. Immunohistochemical staining also demonstrated that EEAM induced the downregulation of Bax and upregulation of Hsp70 proteins after pretreatment. Collectively, the present results suggest that EEAM has a promising antiulcer potential, which could be attributed to its suppressive effect against oxidative damage and preservative effect toward gastric wall mucus.
\end{abstract}

Keywords: Annona muricata, annonaceae, gastric injury, antioxidants, Hsp70/Bax

\section{Introduction}

Peptic ulcer is a debilitating disease which affects 4 million people of all ages globally each year. ${ }^{1,2}$ This prevalent gastrointestinal disorder is defined as integrity disturbance of the duodenum or gastric mucosa, which is characterized by mucosal damage due to gastric acid and pepsin secretion. ${ }^{3,4}$ The gastrointestinal inflammation caused by a peptic ulcer can deteriorate into a perforated peptic ulcer and become a life-threatening disease, with the mortality rate of $10 \%-40 \% .^{5-7}$ The increased incidence of contributing factors to peptic ulcer among people, including alcohol consumption, nutritional deficiencies, smoking, and stress has made this disease a major health problem of global concern. ${ }^{8-10}$ In addition, the available therapeutic drugs for peptic ulcers have failed to meet pharmacological expectations, to a certain degree, due to arrhythmia, gynecomastia, hypersensitivity, impotence, and hematopoietic changes of drugs, including anticholinergics, $\mathrm{H}_{2}$-receptor antagonists, and proton pump inhibitors. ${ }^{11,12}$ Therefore, there is a surge
Correspondence: Habsah Abdul Kadir Biomolecular Research Group, Biochemistry Program, Institute of Biological Sciences, Faculty of Science, University of Malaya, 50603 Kuala Lumpur, Malaysia

Tel +60 379674363

Fax +60379674178

Email habsah@um.edu.my 
of interest in developing new pharmacological agents with gastroprotective effect against peptic ulcers.

Investigation into different diseases at the cellular level and exploring the molecular pathway have provided a new approach for the development of pharmacological products. ${ }^{13}$ In recent studies, it is well established that heat shock proteins (Hsps) have a critical role in the gastric defense mechanism at the intracellular level. ${ }^{14-16}$ Hsp70, as a major molecular chaperone, is responsible for cellular recovery against various stimuli, through modulation of the denatured and unfolded proteins. ${ }^{17,18}$ The protective role of this protein against gastric mucosal damage induced by ulcerogenic conditions and toxic agents has made it a key factor in gastrointestinal studies. ${ }^{19-21}$ Therefore, studies on antiulcer agents with the potential to increase the expression of Hsp70 can lead to the development of new gastroprotective drugs with marked improvements in efficiency.

Annona muricata L., a member of the Annonaceae family, is a widely distributed plant in Central and South America and tropical countries. ${ }^{22,23}$ Also known as soursop and graviola, this small tropical tree plant has long been cultivated by native peoples, due to its extensive applications in folk medicine and heart-shaped, edible fruits. ${ }^{24,25}$ The lanceolate dark green leaves of $A$. muricata are traditionally used as an antispasmodic nervine for heart conditions and as a sedative. In addition, the leaves are applied to treat asthma, cough, fever, headache, hypertension, and toothache. ${ }^{24,26,27}$ The leaves of $A$. muricata have been found to possess significant antioxidant effects, assessed by 2,2-diphenyl-1-picrylhydrazyl (DPPH) radical-scavenging activity, ferric reducing antioxidant power, and hydroxyl-scavenging activity techniques in animal models. $^{23,26,28}$ In addition, the leaves demonstrated a notable protective effect against acute and chronic inflammations in rats, through suppression of proinflammatory cytokines. ${ }^{29}$ Previous studies have shown that the main chemical constituents in A. muricata are annonaceous acetogenins, alkaloids, and essential oils. ${ }^{24}$ Due to the significant antioxidant and anti-inflammatory features of $A$. muricata leaves, this plant may be a promising candidate for antiulcer agents. Hence, the present study was carried out to investigate the acute toxicity and gastroprotective activity of $A$. muricata leaves against ethanol-induced gastric injury in rats.

\section{Materials and methods}

\section{Plant collection and preparation of the ethyl acetate extract}

The leaves of $A$. muricata were collected from Ipoh, Malaysia, in June 2013. The plant was authenticated by Dr Yong
Kien Thai, Institute of Biological Sciences, University of Malaya. A voucher specimen has been deposited at the herbarium of the University of Malaya (Number KLU47978). The leaves were dried at $35^{\circ} \mathrm{C}$ and subsequently powdered $(1,981 \mathrm{~g})$, followed by maceration at room temperature with ethyl acetate for 4 days. After filtering the extract, the solvent was removed using a rotary evaporator (Buchi, Germany) at $40^{\circ} \mathrm{C}$. The percentage yield after extraction, three times with ethyl acetate was $4.1 \%$ (81.3 g).

\section{Drugs and chemicals}

In this study, omeprazole (Sigma-Aldrich, St Louis, MO, USA) was used as the reference antiulcer medicine. All substances administered to animals, including ethyl acetate extract of $A$. muricata leaves (EEAM) and omeprazole, were dissolved in the vehicle $\left(5 \%\right.$ Tween $\left.^{\circledR} 20\right)$.

\section{Chemical analysis of EEAM}

Chemical profiling of EEAM was carried out using an Agilent, a LECO Restek Rxi ${ }^{\circledR}$-5MS capillary column (30 minutes, $0.25 \mathrm{~mm}$ internal diameter, $0.25 \mu \mathrm{m}$ film thickness), and a LECO Pegasus ${ }^{\circledR}$ HT high throughput time-of-flight mass spectrometer, as previously described in detail. ${ }^{30}$ The carrier gas was helium, at a flow rate of $1 \mathrm{~mL}$ per minute (min). Column temperature was initially $40^{\circ} \mathrm{C}$ for $5 \mathrm{~min}$, then gradually elevated to $160^{\circ} \mathrm{C}$ at $4^{\circ} \mathrm{C} / \mathrm{min}$, and finally increased to $280^{\circ} \mathrm{C}$ at $5^{\circ} \mathrm{C} / \mathrm{min}$ and held for $10 \mathrm{~min}$. For gas chromatographymass spectrometry detection, an electron ionization system was used, with ionization energy of $70 \mathrm{eV}$. The fraction was diluted 1:100 (by volume) with ethyl acetate, and 1.0 $\mu \mathrm{L}$ of the diluted sample was injected automatically in splitless mode. Injector temperature was set at $250^{\circ} \mathrm{C}$. Compounds were identified from their mass spectra, by comparison of the retention times of peak with interpretation of mass spectroscopy fragmentation patterns from the National Institute of Standards and Technology (NIST147) mass specteral database.

\section{Animals}

Adult and healthy Sprague Dawley ${ }^{\circledR}$ strain rats (180-250 g) of both sexes were obtained from Animal House, Faculty of Medicine, University of Malaya (Kuala Lumpur, Malaysia). Animals were housed at controlled room temperature $\left(\sim 24^{\circ} \mathrm{C}\right)$ with free access to standard rat pellets and tap water ad libitum, under an artificial lighting system (daily ratio 1:1). The experiments were carried out after approval of the protocol by the committee for animal experimentation, Faculty of Medicine, University of Malaya (Ethic Number 2014-03-05/PHAR/R/SZM). 


\section{Toxicity evaluation of EEAM}

Eighteen female rats (6-8 weeks old) were divided into three groups ( $\mathrm{n}=6)$, namely, vehicle, low dose, and high dose, and orally administered with Tween 20 (5\%), $1 \mathrm{~g} / \mathrm{kg}$ EEAM, and $2 \mathrm{~g} / \mathrm{kg}$ EEAM, respectively. Prior to dosing, rodents were fasted overnight (water was accessible), and fasting was continued for 3 hours after dosing. The rats were then monitored for mortality, if any, or any other sign of toxicological symptoms twice per day during a period of 2 weeks. On day 15 , the rats were euthanized using an overdose of xylazine and ketamine, and tested for biochemical parameters and histological examinations of liver and kidney.

\section{Ethanol-induced gastric injury}

The experiment was performed as previously described in detail. ${ }^{31}$ After 24 hours of fasting (water was accessible except for the last 2 hours), the 30 male rats ( $n=6$ per group) in five groups were pretreated according to Table 1. To induce gastric injury, 1 hour after treatment, all the rodents were orally administered with absolute ethanol $(5 \mathrm{~mL} / \mathrm{kg})$, except for the normal control group, which was administered with $5 \%$ Tween 20 . The rats were euthanized 1 hour later with an overdose of xylazine and ketamine, and their stomachs were removed and prepared for further analysis.

\section{Macroscopic evaluation of lesions}

After rinsing the stomachs of the rats with water to remove blood clots and gastric contents, they were opened along the greater curvature and fixed to examine the gastric lesion index, as previously described..$^{32}$ Microscopic scores were calculated, based on the following parameters: edema or hemorrhage, loss of mucosal folding, mucosal discoloration (score: 1 each); ulcers less than $1 \mathrm{~mm} / \mathrm{cm}^{2}$ (score: number of ulcers $\times 2$ ); ulcers more than $1 \mathrm{~mm} / \mathrm{cm}^{2}$ (score: number of ulcers $\times 3$ ); perforated ulcers (score: number of ulcers $\times 4$ ).

Table I The experimental design and specifications

\begin{tabular}{llll}
\hline Group & Description & Pretreatment & Treatment \\
\hline A & Normal & $5 \%$ Tween $^{\circledR} 20$ & $5 \%$ Tween 20 \\
& control & $(5 \mathrm{~mL} / \mathrm{kg})$ & \\
B & Ulcer & $5 \% \mathrm{Tween} 20$ & Absolute ethanol \\
& control & $(5 \mathrm{~mL} / \mathrm{kg})$ & \\
C & Low dose & EEAM & Absolute ethanol \\
& & $(200 \mathrm{mg} / \mathrm{kg})$ & \\
D & High dose & EEAM & Absolute ethanol \\
& & $(400 \mathrm{mg} / \mathrm{kg})$ & \\
E & Omeprazole & Omeprazole & Absolute ethanol \\
& control & $(20 \mathrm{mg} / \mathrm{kg})$ & \\
\hline
\end{tabular}

Abbreviation: EEAM, ethyl acetate extract of Annona muricata leaves.

\section{Evaluation of the loss in gastric wall mucus (GWM) and gastric juice acidity}

To determine gastric juice acidity, the stomachs were dissected and the contents were drained into falcon tubes and centrifuged at 3,000 rpm for $15 \mathrm{~min}$. Then, gastric acidity was measured using a digital $\mathrm{pH}$ meter. Perturbation in GWM was determined for each group. ${ }^{33}$ In brief, the glandular segments of each stomach were removed prior to immersing the stomach tissue in $1 \%$ alcian blue solution (in sucrose solution, buffered with sodium acetate at $\mathrm{pH} 5$ ). Then, the excess dye was removed by rinsing with sucrose solution. Magnesium chloride solution was used to extract the dye complexed with GWM. After mixing the extract with diethyl ether, the level of GWM in each group was determined through measurement of the absorbance at $580 \mathrm{~nm}$. The quantity of GWM was expressed as $\mu \mathrm{g}$ of alcian blue per gram of tissue.

\section{Enzymatic activities of stomach tissue homogenate}

Preparation of the gastric tissue homogenate $(150 \mathrm{mg}$ tissue $/ \mathrm{mL}$ phosphate buffered saline) for each rat was performed using a teflon homogenizer (Polytron, Heidolph, Germany). Then, the supernatant of tissue homogenate was isolated after centrifugation at 4,000 rpm for $10 \mathrm{~min}$ and used for further assessment of enzymatic activities. The levels of catalase (CAT), glutathione (GSH), nitric oxide (NO), and superoxide dismutase (SOD) were determined using commercial kits (Cayman Chemical, Ann Arbor, MI, USA), according to the vendor's instructions. In addition, determination of the levels of malondialdehyde (MDA) and prostaglandin E2 (PGE-2) was also carried out using commercial kits (Cayman Chemical), based on the protocols provided by the manufacturer.

\section{Histopathology}

Stomachs were fixed in $10 \%$ formalin. For microscopic analysis, after processing the tissues in a paraffin tissueprocessing machine (Leica Microsystems Incorporated, Nussloch, Germany), $5 \mu \mathrm{m}$ sections of tissue were stained with hematoxylin and eosin (H\&E) dye and Periodic acid-Schiff (PAS) dye (Sigma-Aldrich), to examine tissue architecture, and changes in glycogen and generated mucus, respectively. Lastly, a light microscope (Nikon, Tokyo, Japan) was used to observe the gastric sections.

\section{Immunohistochemistry evaluation}

Immunohistochemistry analysis of Bax and Hsp70 was carried out, as previously described in detail. ${ }^{34,35}$ Briefly, 
after processing the specimens of gastric tissue as previously mentioned, $5 \mu \mathrm{m}$ sections were fixed on 3-aminopropyltrimethoxysilane-(APES) treated glass slides and supplemented with Bax and Hsp70 (Abcam, Cambridge, MA, USA), for immunohistochemical staining using a streptavidin peroxidase (Abcam). The slides were then observed under a light microscope with brown color representing positive immunohistochemical staining.

\section{Statistical analysis}

All values were reported as mean \pm standard error of $n$ animals per group. Statistical evaluation of the data was carried out using one-way analysis of variance, followed by Tukey's test. In the cases of ulcer index and gastric juice acidity, data were analysed using the Kruskal-Wallis test, and Dunn's multiple comparison test, as a post hoc test. A value of $P<0.05$ was considered significant.

\section{Results and discussion}

Nutraceuticals, including dietary supplements, functional foods, and herbal products have maintained their importance in the treatment of various ailments and diseases, irrespective of the extensive development of synthetic drugs in the pharmaceutical industry. ${ }^{36}$ In recent years, considering the prominence of gastric injury and unpredictable side effects of the long-term use of synthetic drugs, interest in the use of herbal products has markedly elevated. ${ }^{37}$ Previous studies have illustrated that numerous plants from different families, including Annonaceae, possess promising antiulcer properties. ${ }^{37,38}$ An in vitro and in vivo study on A. squamosa, a member of the Annonaceae family, showed that the twigs of this plant possess antiulcer constituents with suppressive effect on $\mathrm{H}^{+}$ $\mathrm{K}^{+}$-ATPase activity. ${ }^{39}$ Uvaria chamae leaves (Annonaceae), with extensive application in folk medicine, are an antiulcer herb, scientifically proven to have antiulcer activity in rats. ${ }^{40}$ Polyalthia longifolia, belonging to the Annonaceae family, was found to have anti-inflammatory and antiulcer properties in its fresh leaves, associated with antioxidant activity. ${ }^{41,42}$ In the current study, we investigated the antiulcer effects of EEAM against ethanol-induced gastric injury in rats.

\section{Chemical profiling of EEAM}

The chemical profiling of EEAM showed the presence of two major compounds, namely, caryophyllene and $\alpha$-copaene (Figure 1). Previous studies showed that among 80 essential oil compounds detected in A. muricata leaves, caryophyllene was the most abundant constituent (13.6\%). ${ }^{43,44}$ A recent investigation exhibited that the antioxidant effect of $\beta$-caryophyllene can effectively protect the rat liver from carbon tetrachloride-induced fibrosis, by suppressing hepatic stellate cell activation. ${ }^{45}$ Caryophyllene oxide isolated from the bark of $A$. squamosa demonstrated significant anti-inflammatory and analgesic activities. ${ }^{46}$ In addition, $\alpha$-copaene was also reported as one of the significant chemical constituents $(2.0 \%-7.3 \%)$ detected in volatile oil contents of $A$. muricata. ${ }^{47}$ Caryophyllene and $\alpha$-copaene were previously found to have promising antioxidant activity when they were isolated from $A$. salzmannii. ${ }^{48}$ Considering the anti-inflammatory and antioxidant activities reported for caryophyllene and $\alpha$-copaene, as the major compounds detected in EEAM, this extract may be a potential antiulcer candidate against ethanol-induced gastric injury in rats.

\section{EEAM safety}

Examination of acute toxicity is the first step in the study of the biological activities of plants. ${ }^{49}$ In this study, no mortality in rats was observed with two concentrations of the EEAM extract ( $1 \mathrm{~g} / \mathrm{kg}$ and $2 \mathrm{~g} / \mathrm{kg}$ ). After 2 weeks of treatment with EEAM, the rats did not demonstrate important changes in body weight, behavior (ie, ataxia, hypoactivity, and hyperactivity), microscopic morphology, and functional tests of kidney and liver (Table 2 and Figure 2). From these results, it is concluded that EEAM is quite safe, even at the highest dose of $4 \mathrm{~g} / \mathrm{kg}$, with no detectable sign of acute toxicity; the oral lethal dose $\left(\mathrm{LD}_{50}\right)$ of EEAM in rats was higher than $2 \mathrm{~g} / \mathrm{kg}$ body weight. Our result was comparable with a previous investigation on the ethanol extract from $A$. muricata leaves, which showed an $\mathrm{LD}_{50}$ of $1.67 \mathrm{~g} / \mathrm{kg}$ in mice, presenting high

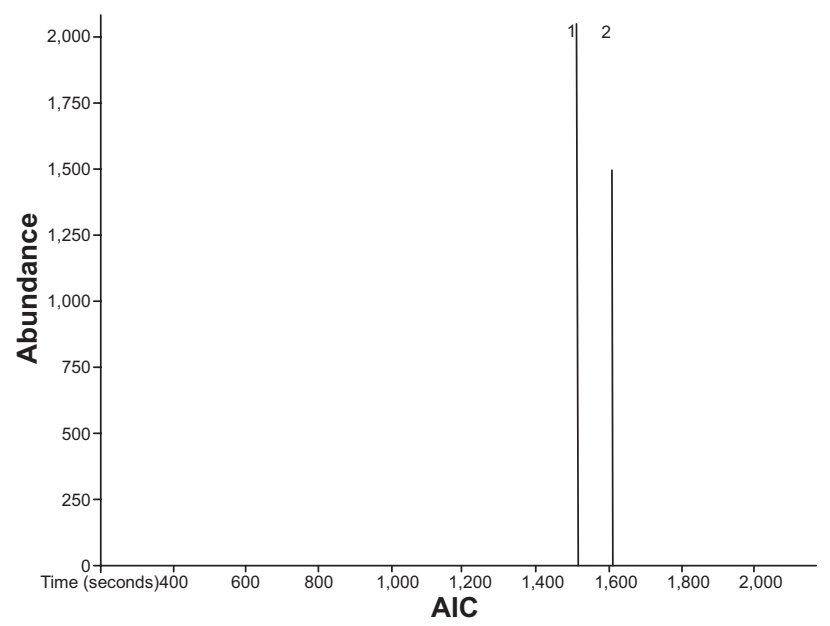

Figure I A chromatogram analysis of EEAM, characterized with the GC-MS-TOF. Notes: GC-MS-TOF analysis demonstrated the presence of two major compounds, namely (I) caryophyllene and (2) $\alpha$-copaene.

Abbreviations: EEAM, ethyl acetate extract of Annona muricata leaves; GC-MSTOF, gas chromatography-time-of-flight mass spectrometry; AIC, analytical ion chromatogram. 
Table 2 Effects of EEAM on renal and liver function tests of rats after 14 days of acute toxicity study did not show any significant differences between vehicle control and EEAM treated groups

\begin{tabular}{|c|c|c|c|c|c|c|c|c|}
\hline \multicolumn{9}{|c|}{ Renal function test } \\
\hline Group & $\begin{array}{l}\text { Sodium } \\
\text { (mM/L) }\end{array}$ & $\begin{array}{l}\text { Potassium } \\
\text { (mM/L) }\end{array}$ & $\begin{array}{l}\text { Chloride } \\
\text { (mM/L) }\end{array}$ & $\begin{array}{l}\mathrm{CO}_{2} \\
(\mathrm{mM} / \mathrm{L})\end{array}$ & $\begin{array}{l}\text { Anion } \\
(\mathrm{mM} / \mathrm{L})\end{array}$ & & $\begin{array}{l}\text { Urea } \\
(\mathrm{mM} / \mathrm{L})\end{array}$ & $\begin{array}{l}\text { Creatinine } \\
(\mu \mathrm{M} / L)\end{array}$ \\
\hline Vehicle & $|4| .5 \pm 0.6$ & $3.91 \pm 0.05$ & $105.7 \pm 0.9$ & $23.1 \pm 0.2$ & $17.3 \pm 0.4$ & & $6.3 \pm 0.2$ & $30.6 \pm 1.5$ \\
\hline $\mathrm{l} g / \mathrm{kg}$ & $140.6 \pm 0.3$ & $4.14 \pm 0.07$ & $104.3 \pm 1.1$ & $24.4 \pm 0.3$ & $16.6 \pm 0.3$ & & $5.8 \pm 0.1$ & $30.7 \pm 1.2$ \\
\hline $2 \mathrm{~g} / \mathrm{kg}$ & $140.7 \pm 0.4$ & $4.22 \pm 0.03$ & $104.4 \pm 1.0$ & $25.1 \pm 0.2$ & $16.9 \pm 0.6$ & & $5.6 \pm 0.2$ & $31.8 \pm 1.1$ \\
\hline \multicolumn{9}{|c|}{ Liver function test } \\
\hline Group & $\begin{array}{l}\text { Total protein } \\
\text { (g/L) }\end{array}$ & $\begin{array}{l}\text { Albumin } \\
\text { (g/L) }\end{array}$ & $\begin{array}{l}\text { Globulin } \\
\text { (g/L) }\end{array}$ & $\begin{array}{l}\text { TB } \\
(\mu \mathrm{M} / \mathrm{L})\end{array}$ & $\begin{array}{l}\text { AP } \\
(U / L)\end{array}$ & $\begin{array}{l}\text { ALT } \\
(\mathrm{U} / \mathrm{L})\end{array}$ & $\begin{array}{l}\text { AST } \\
(U / L)\end{array}$ & $\begin{array}{l}\text { GGT } \\
(\mathrm{U} / \mathrm{L})\end{array}$ \\
\hline Vehicle & $70.5 \pm 0.7$ & $35.4 \pm 0.8$ & $27.3 \pm 0.8$ & $3.1 \pm 0.1$ & $160.4 \pm 2.4$ & $27.4 \pm 0.9$ & $25.1 \pm 2.2$ & $1.1 \pm 0.1$ \\
\hline $\mathrm{l} g / \mathrm{kg}$ & $71.4 \pm 0.3$ & $36.6 \pm 0.4$ & $26.5 \pm 0.4$ & $3.2 \pm 0.2$ & $159.3 \pm 1.9$ & $28.2 \pm 1.1$ & $27.5 \pm 1.5$ & $1.0 \pm 0.1$ \\
\hline $2 \mathrm{~g} / \mathrm{kg}$ & $71.7 \pm 0.8$ & $37.1 \pm 0.2$ & $26.1 \pm 0.2$ & $3.2 \pm 0.1$ & $158.5 \pm 2.5$ & $28.9 \pm 1.5$ & $26.3 \pm 1.4$ & $1.2 \pm 0.1$ \\
\hline
\end{tabular}

Notes: Values expressed as mean \pm SEM. A value of $P<0.05$ was considered significant.

Abbreviations: EEAM, ethyl acetate extract of Annona muricata leaves; TB, total bilirubin; AP, alkaline phosphatase; ALT, alanine aminotransferase; AST, aspartate aminotransferase; GGT, gamma-glutamyl transferase; SEM, standard error of the mean.

safety of A. muricata leaves. ${ }^{50}$ However, a previous study on the acute toxicity of $A$. muricata leaf aqueous extract reported the relatively low $\mathrm{LD}_{50}$ value of $155 \mathrm{mg} / \mathrm{kg}$ in mice, which showed moderate safety of aqueous extract in mice. ${ }^{27}$

\section{Macroscopic analysis of gross appearances of stomach and gastric ulcer index}

The rodents that were administrated with absolute ethanol experienced severe macroscopic damage, compared to the normal control group (Figure 3A), which was evidenced by development of hemorrhagic ulceration (Figure 3B). The consequent hemorrhagic detriment was conspicuously attenuated by pretreatment with EEAM at $200 \mathrm{mg} / \mathrm{kg}$ and $400 \mathrm{mg} / \mathrm{kg}$ doses, with a few fields of hyperemia (Figure 3C and 3D). In addition, rats with prior administration of omeprazole $(20 \mathrm{mg} / \mathrm{kg})$ were able to suppress damage to the stomach, showing similar features to the normal control group (Figure 3E). Macroscopic analysis of the gross appearances of the stomach demonstrated that EEAM administration, especially at $400 \mathrm{mg} / \mathrm{kg}$ dose, had a protective effect against ethanol-induced gastric injury, which was comparable to the protective effect of omeprazole, as a standard antiulcer drug.

In the ethanol-induced gastric injury model, pretreatment with EEAM at $200 \mathrm{mg} / \mathrm{kg}$ and $400 \mathrm{mg} / \mathrm{kg}$ doses
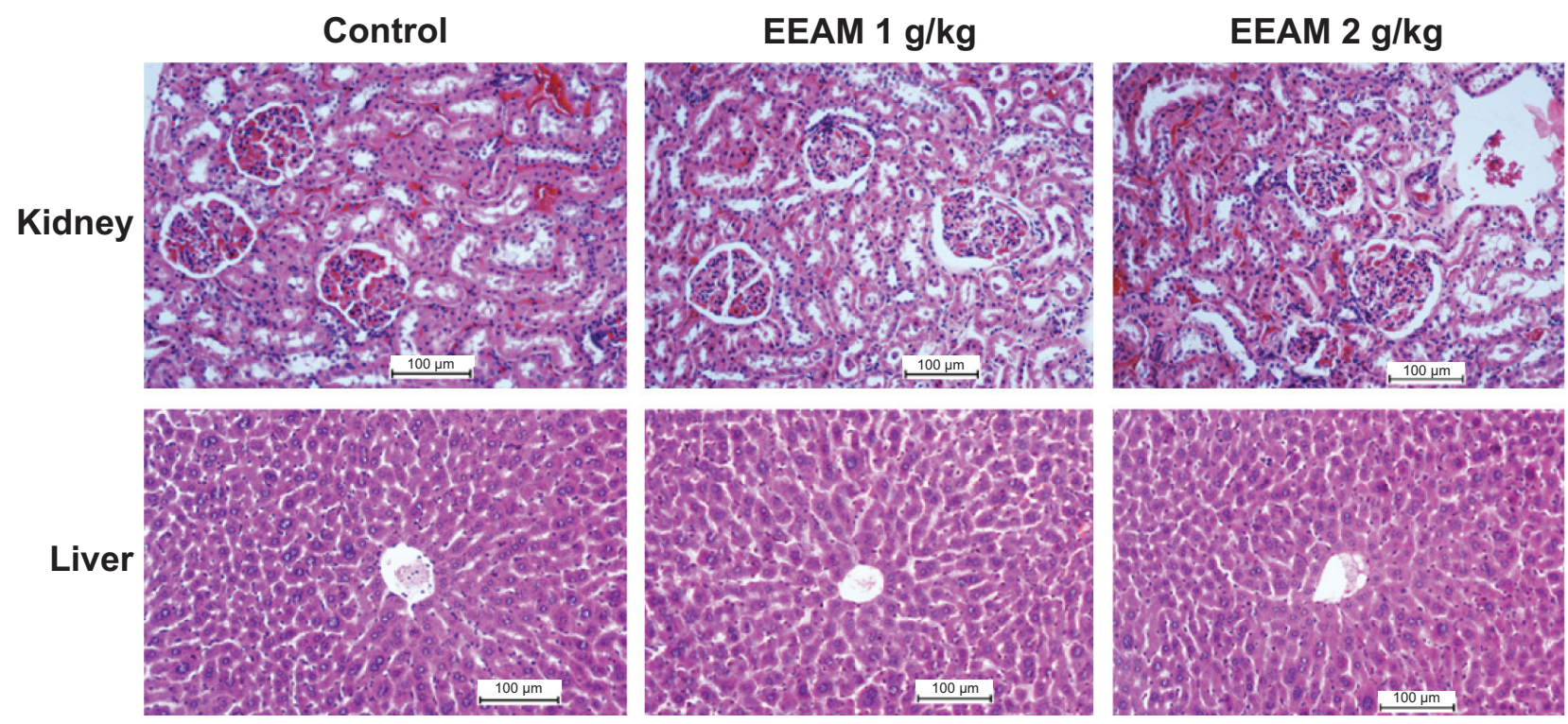

Figure 2 Histopathology analysis (H\&E staining, 20x) of kidney and liver from control, EEAM at I g/kg, and EEAM at 2 g/kg demonstrated no significant differences in the structures of kidney and liver between vehicle control and EEAM-treated groups.

Abbreviations: EEAM, ethyl acetate extract of Annona muricata leaves; H\&E, hematoxylin and eosin. 

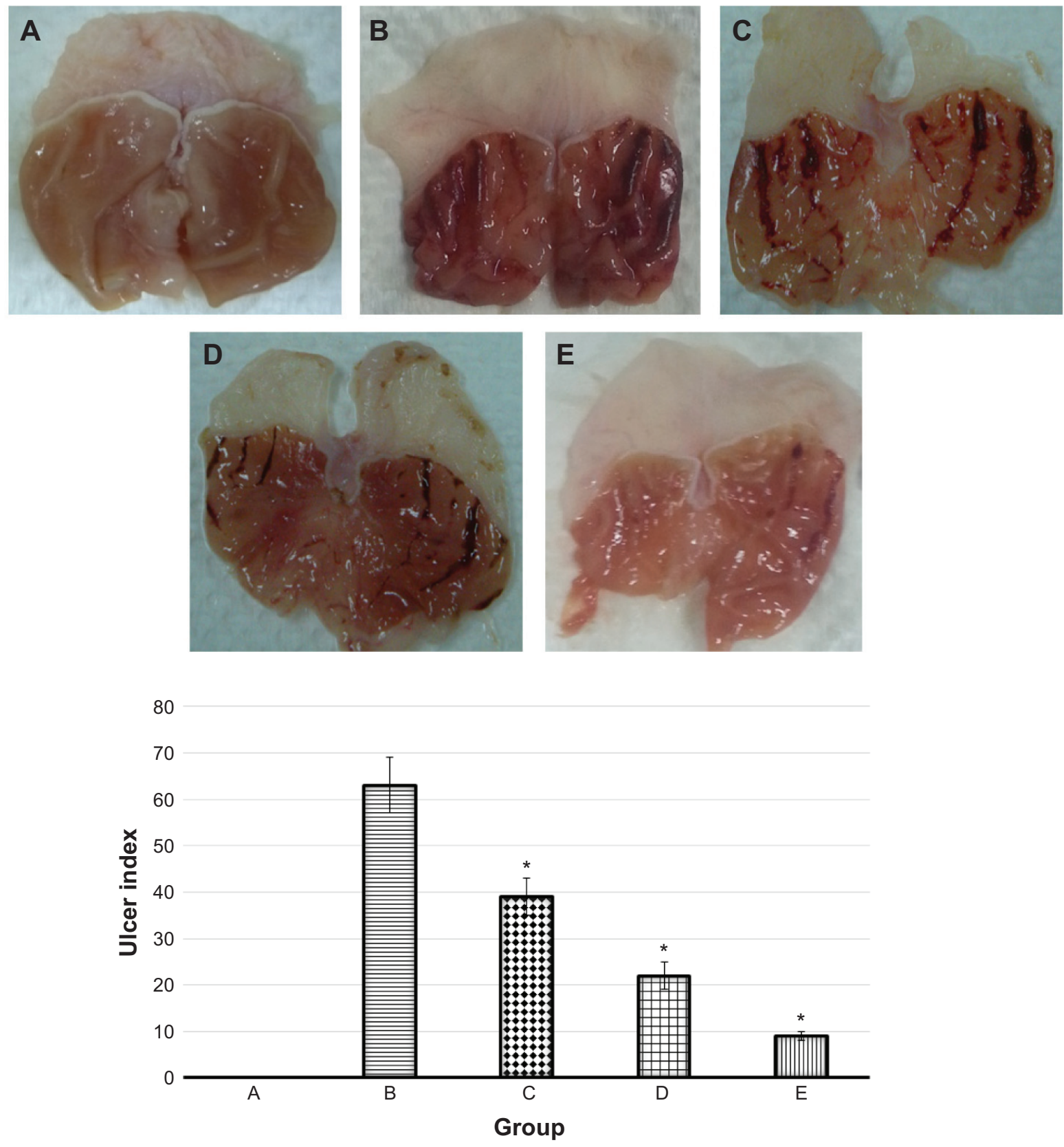

Figure 3 Gross appearances of stomach from five groups of rats, namely: (A) normal control, (B) lesion control, (C) low dose of EEAM, (D) high dose of EEAM, and (E) omeprazole control. Quantitative analysis of ulcer index showed significant reduction in the ulcer index after pretreatment with EEAM (200 $\mathrm{mg} / \mathrm{kg}$ and $400 \mathrm{mg} / \mathrm{kg})$, and omeprazole.

Notes: Data are reported as means \pm SEM of six animals per group. Statistical comparison was performed using the Kruskal-Wallis test, followed by the Dunn test. A value of $* P<0.05$ was considered significant.

Abbreviations: EEAM, ethyl acetate extract of Annona muricata leaves; SEM, standard error of the mean.

caused significant inhibition on the ulcer lesion index, compared to the ulcer control group (Figure 3). In addition, there was a significant reduction in all the gastric ulcer parameters after preadministration with omeprazole, as a standard antiulcer drug (Figure 3). This proton pump inhibitor drug has been extensively used to treat various ailments regarding gastric acid secretion. ${ }^{51}$ Besides the antisecretory effect of omeprazole in acid-dependent ulcer models, it is well known to have a mucosal protective effect in non-antisecretory doses. ${ }^{52}$ The noteworthy healing rates of omeprazole among patients suffering from peptic ulcer are mainly due to its gastric mucosa-protective effect, associated with the ability to suppress gastric juice acidity via proton pump inhibitory activity. ${ }^{53}$ Therefore, any herbal medicine with the same protective effects may possibly show promising antiulcer potential. ${ }^{54}$ Hence, in the next 
step of this study, we investigated the effect of EEAM on GWM and gastric juice acidity.

\section{EEAM protected the GWM and attenuated gastric juice acidity}

Among the various factors involved in the intensification of lesion ulcers, exogenous gastric acid is known to be a crucial aggressive factor in the stomach. ${ }^{55}$ The excessive production of gastric acid in patients suffering from peptic ulcers can severely intensify the gastric injury, which generally parallels reduction in the level of GWM. ${ }^{56}$ Perturbation in the balance between aggressive factors and defensive factors, including cellular mucus, cell proliferation, cell shedding, and mucus secretion, results in gastric hyperacidity. ${ }^{57}$ In patients with peptic ulcers, proton pump inhibitors attenuate acid secretion in the stomach and recover the production of GWM. ${ }^{4}$ It is well established that ethanol is a potent necrotizing agent that severely damages the protective factors of the mucosa. ${ }^{58}$ In our study, after administration of ethanol to rats, levels of GWM and $\mathrm{pH}$ were significantly reduced, compared to the normal control group (Figure 4). However, pretreatment of rats with two doses of EEAM caused significant attenuation in gastric acidity, compared to the ulcer control group. In addition, EEAM significantly retrieved the loss in GWM. Nonetheless, rats pretreated with omeprazole had comparatively higher protection of GWM and lower gastric acidity, compared to EEAM at both doses (Figure 4).

\section{EEAM induced changes in enzymatic activities of stomach tissue homogenate}

Administration of absolute ethanol to rodents induced significant reduction in antioxidant activities and NO level of stomach homogenate, compared to the normal control group. Meanwhile, pretreatment with EEAM at two doses, and omeprazole, significantly surged the levels of antioxidant activities and NO (Table 3). It is well established that reactive oxygen species (ROS), including hydrogen peroxide, hydroxyl radicals, and superoxide anions, as an aggressive factor, have a critical role in oxidative damage to the gastric mucosa. ${ }^{59}$ Cellular antioxidants maintain ROS at their physiological levels to attenuate tissue damages. The higher level of GSH was found to minimize oxidative damages. ${ }^{60}$ By converting into glutathione disulfide; this tripeptide with thiol groups reduces cellular ROS. ${ }^{61}$ In addition, SOD has a scavenging effect against ROS, by converting the superoxide to hydrogen peroxide, which is subsequently converted to water by CAT. ${ }^{62}$

One of the important factors for the slow flow of gastric blood, which leads to the development of hemorrhagic lesions and subsequent solubilization of gastric mucus contents, was found to be a reduction in the level of NO. This leads to an elevation in the flow of $\mathrm{K}^{+}, \mathrm{Na}^{+}$, and pepsin secretion associated with a loss in the level of $\mathrm{H}^{+}$ions. ${ }^{63}$ The protective barrier produced by $\mathrm{NO}$, through the suppression of neutrophil infiltration, inhibits gastric damage from ethanol. ${ }^{64}$ Through an inhibitory effect on neutrophil infiltration, NO also attenuates the secretion of inflammatory mediators. ${ }^{65}$ Therefore, antiulcer agents with the ability to promote NO production can provide a more protective effect against gastric lesions.

The level of MDA, as a final product of lipid peroxidation, is an easy biomarker to determine oxidative stress. ${ }^{66}$ Lipid peroxidation is mediated by neutrophils, via generation of superoxide anions. ${ }^{65}$ As a necrotizing agent, ethanol caused
A

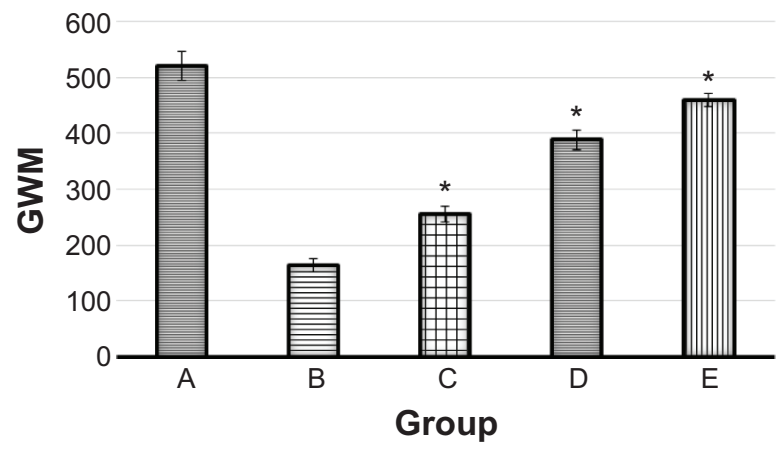

B

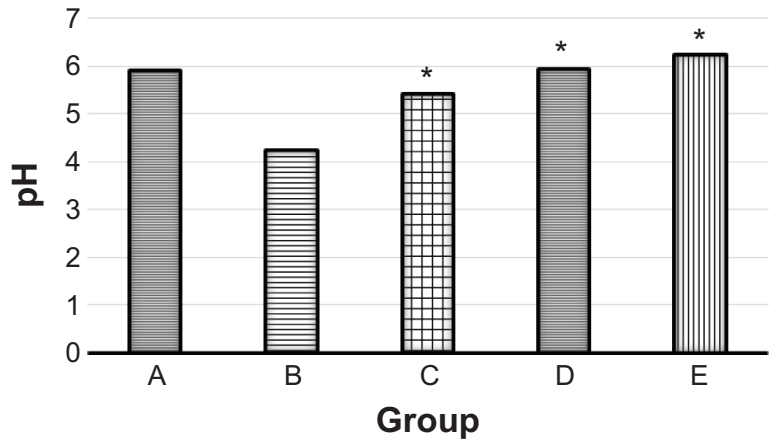

Figure 4 Measurement of (A) GWM ( $\mu$ g of alcian blue per gram of tissue) and (B) pH in five groups of rats, namely: (A) normal control, (B) lesion control, (C) low dose of EEAM, (D) high dose of EEAM, and (E) omeprazole control.

Notes: Data for GWM are reported as means \pm SEM of six animals per group. Statistical comparison for the median pH values was performed using the Kruskal-Wallis test, followed by the Dunn test. A value of $* P<0.05$ was considered significant.

Abbreviations: GWM, gastric wall mucus; EEAM, ethyl acetate extract of Annona muricata leaves; SEM, standard error of the mean. 
Table 3 Effect of EEAM at (C) $200 \mathrm{mg} / \mathrm{kg}$ and (D) $400 \mathrm{mg} / \mathrm{kg}$ doses, and (E) omeprazole on enzymatic activities of stomach tissue homogenate. (A) and (B) are presenting the normal control and lesion control groups, respectively

\begin{tabular}{|c|c|c|c|c|c|c|}
\hline $\begin{array}{l}\text { Animal } \\
\text { group }\end{array}$ & $\begin{array}{l}\text { CAT } \\
\mathrm{nM} / \mathrm{min} / \mathrm{mL}\end{array}$ & $\begin{array}{l}\text { GSH } \\
\text { ( } \mu \mathrm{M} / \mathrm{mg} \text { protein) }\end{array}$ & $\begin{array}{l}\text { NO } \\
\text { ( } \mu \text { M/g protein) }\end{array}$ & $\begin{array}{l}\text { SOD } \\
\text { (U/mg protein) }\end{array}$ & $\begin{array}{l}\text { MDA } \\
\text { ( } \mu \text { M/g protein) }\end{array}$ & $\begin{array}{l}\text { PGE-2 } \\
\text { (ng/mg protein) }\end{array}$ \\
\hline A & $116.11 \pm 4.17$ & $16.49 \pm 0.44$ & $11 \pm 0.9$ & $19.66 \pm 0.25$ & $72.23 \pm 1.1$ & $4.07 \pm 0.09$ \\
\hline B & $70.14 \pm 3.21$ & $9.19 \pm 0.38$ & $5.7 \pm 0.09$ & $10.19 \pm 0.55$ & $168.23 \pm 4.98$ & $2.12 \pm 0.03$ \\
\hline C & $81.53 * \pm 2.11$ & $12.5 \mid * \pm 0.18$ & $7.7^{*} \pm 0.7$ & $12.89 * \pm 0.56$ & $\left|23.88^{*} \pm 6.7\right|$ & $2.8^{*} \pm 0.1$ \\
\hline D & $\left|03.23^{*} \pm 4.2\right|$ & $13.49 * \pm 0.12$ & $9.1 * \pm 1.1$ & $|4.79 * \pm 0.6|$ & $95.22 * \pm 0.22$ & $3.4^{*} \pm 0.7$ \\
\hline E & $113.23 * \pm 5.1$ & $15.02 * \pm 0.33$ & $10.1 * \pm 1$ & $17.11 * \pm 0.7$ & $89.23 * \pm 0.41$ & $3.8^{*} \pm 0.06$ \\
\hline
\end{tabular}

Notes: Data are reported as means \pm SEM of six animals per group. A value of $* P<0.05$ was considered significant.

Abbreviation: EEAM, ethyl acetate extract of Annona muricata leaves; CAT, catalase; GSH, glutathione; NO, nitric oxide; SOD, superoxide dismutase; MDA, malondialdehyde; PGE-2, prostaglandin E2; SEM, standard error of the mean.

an increase in the level of MDA, ${ }^{67}$ which was observed in our study after administration of absolute ethanol to rats in the normal control group (Table 3). As is to be expected, due to the elevation in the activity of antioxidants, pretreatment with EEAM significantly suppressed MDA production in gastric tissue, which was close to the omeprazole effect (Table 3).

Prostaglandins, due to the regulatory effect on the function of the gut, have promising potential in the treatment of different gastric ailments. ${ }^{68}$ PGE-2 with E prostanoid receptors has a critical role in the motility and secretion of the stomach. Previous studies have shown that the cytoprotective effect of PGE-2 provides noteworthy resistance to gastric mucosal cells against strong irritants, including ethanol. ${ }^{69,70}$ In our study, the ulcer control group showed significant reduction in the level of PGE-2, while rats in groups $\mathrm{C}-\mathrm{E}$ demonstrated compensatory increases. However, omeprazole administration to rats caused the highest level of PGE-2 in gastric tissue homogenates (Table 3).

\section{Histopathological effect of EEAM on gastric lesions}

As was observed in the macroscopic appearance, histological analysis of the gastric tissues also demonstrated various microscopic characterizations, as illustrated in Figures 5 and 6. H\&E staining of the gastric tissues illustrated the severe superficial injury induced by ethanol (Figure 5). Apparent features of gastric ulcers, including edema and leukocyte infiltration, were observed in the lesion control group. Histological analysis indicated that oral administration of EEAM (200 mg/kg and $400 \mathrm{mg} / \mathrm{kg}$ doses), and omeprazole, markedly protected the gastric tissues from hemorrhagic lesions associated with attenuation of leukocyte infiltration


Figure 5 Histopathological staining of gastric tissues after treatment with EEAM at (C) $200 \mathrm{mg} / \mathrm{kg}$ and (D) $400 \mathrm{mg} / \mathrm{kg}$ doses, and (E) omeprazole, using H\&E staining (20×). (A) and (B) are presenting the normal control and lesion control groups, respectively. In the lesion control group, there are clear signs of severe damage to the surface epithelium (white arrow) and leukocyte infiltration (yellow arrow).

Abbreviations: EEAM, ethyl acetate extract of Annona muricata leaves; H\&E, hematoxylin and eosin. 
A

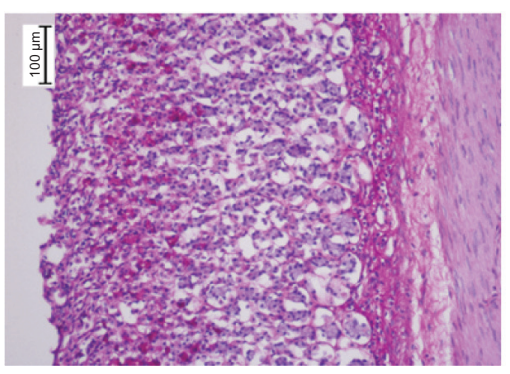

D
B

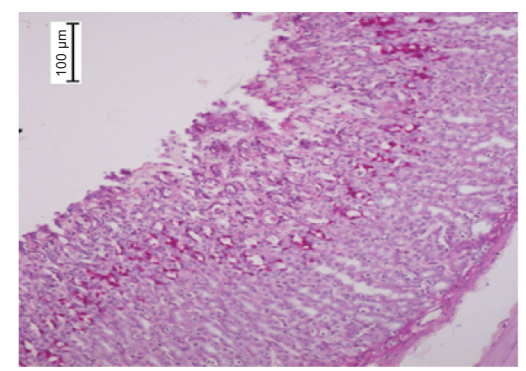

E
C

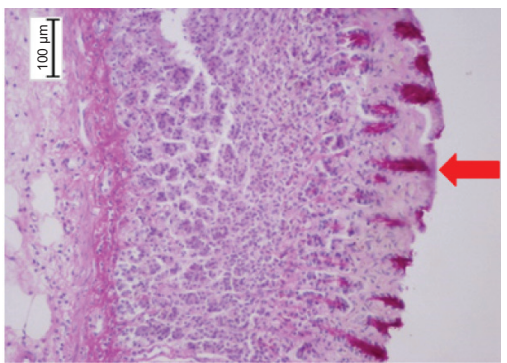

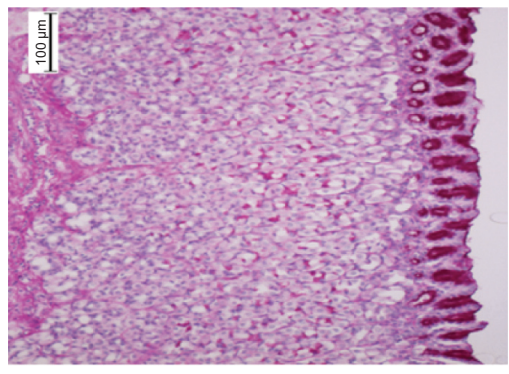

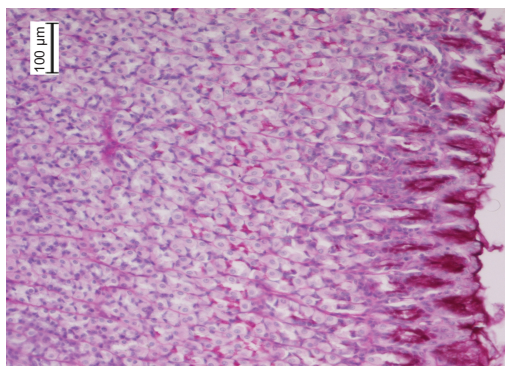

Figure 6 Histopathological staining of gastric tissues after treatment with EEAM at (C) $200 \mathrm{mg} / \mathrm{kg}$ and (D) $400 \mathrm{mg} / \mathrm{kg}$ doses, and (E) omeprazole, using PAS staining (20×). (A) and (B) are presenting the normal control and lesion control groups, respectively. PAS staining illustrated the glycogen accumulation (red arrow) in rats pretreated with EEAM and omeprazole.

Abbreviations: EEAM, ethyl acetate extract of Annona muricata leaves; PAS, Periodic acid-Schiff.

and submucosal edema. In spite of a conspicuous protective effect of EEAM, the sign of hemorrhagic lesions was clearly evident in EEAM $200 \mathrm{mg} / \mathrm{kg}$ pretreated rats. Nonetheless, administration of EEAM at $400 \mathrm{mg} / \mathrm{kg}$ dose, and omeprazole, demonstrated approximately the same characterizations as the normal control group (Figure 5).

Glycogen production in the gastric epithelium was examined using PAS staining. The glycogen content in gastric mucosa, presented as magenta color in PAS staining, showed an almost similar level in all groups of rats, except the lesion control, which suggested a collapse in glycogen production in this group (Figure 6). The PAS staining intensity was elevated in the pretreated groups of rats, with EEAM and omeprazole, compared to the lesion control group, showing the beneficial effect of EEAM on glycogen generation. Induction of glycogen formation by EEAM at $400 \mathrm{mg} / \mathrm{kg}$ dose approximates the effect of omeprazole. The findings of histopathological staining confirmed the role of EEAM, particularly at $400 \mathrm{mg} / \mathrm{kg}$ dose, in the enhancement of mucus level.

\section{EEAM induced up-regulation of Hsp70 and down-regulation of $\mathrm{Bax}$}

Hsp70, a low-molecular weight chaperone and a member of the four families of heat shock proteins, has a critical role in the posttranslational characterizations of polypeptides. ${ }^{71}$ Previous studies have shown the cytoprotective role of
Hsp70 against different stress conditions. ${ }^{72-74}$ In the current study, immunohistochemical analysis showed that mucosal expression of Hsp70 was upregulated in EEAMand omeprazole-pretreated groups (Figure 7). However, accumulation of Hsp 70 in the gastric tissue of rats pretreated with omeprazole was comparable to rats pretreated with EEAM. The normal control group also elicited a higher level of Hsp70 expression, compared to the lesion control group (Figure 7).

A Bcl-2 family of proteins, with 25 members, consists of two groups of proapoptotic and antiapoptotic proteins. ${ }^{75} \mathrm{Bax}$, a proapoptotic protein, promotes the induction of apoptosis in stressed cells via mitochondrial-initiated events. ${ }^{76,77}$ Therefore, an inhibitory effect on Bax protein expression attenuates cellular damage to the gastric tissue. ${ }^{78}$ As illustrated in Figure 8 , the expression of Bax protein in the lesion control group was markedly higher, compared to the normal control group, representing the undergoing process of apoptosis among gastric cells. In pretreated rats with EEAM at $200 \mathrm{mg} / \mathrm{kg}$ and $400 \mathrm{mg} / \mathrm{kg}$ doses, and omeprazole, accumulation of Bax protein in gastric tissue was noticeably reduced (Figure 8). Administration of EEAM (400 mg/kg), and omeprazole, reduced Bax protein expression to approximately the level of the normal control group. However, rats treated with EEAM at $200 \mathrm{mg} / \mathrm{kg}$ dose still elicited the accumulation of Bax protein in gastric tissue (Figure 8). 

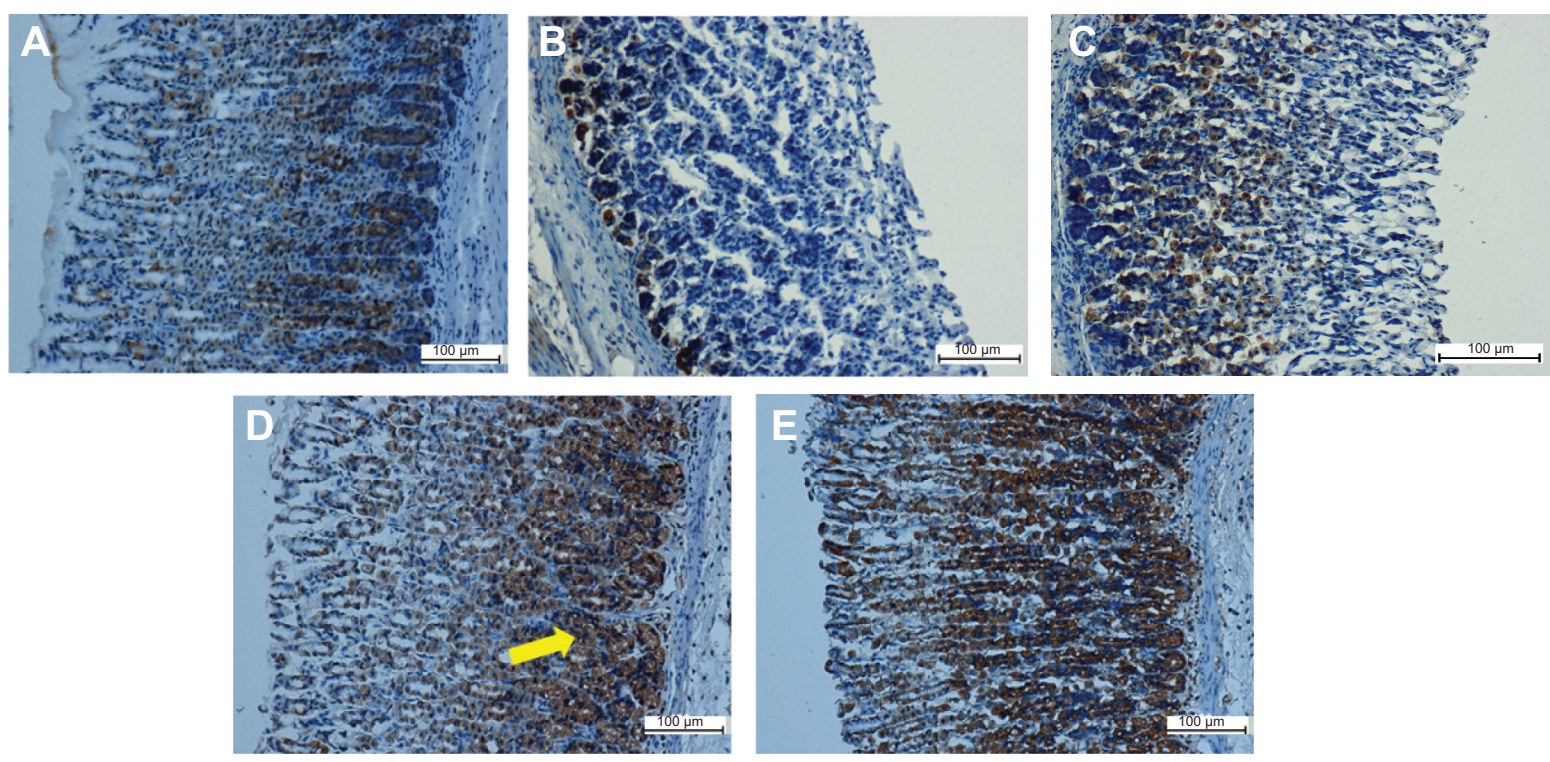

Figure 7 Immunohistochemical analysis of Hsp70 expression from five groups of rats, namely: (A) normal control, (B) lesion control, (C) low dose of EEAM, (D) high dose of EEAM, and (E) omeprazole control. Immunohistochemistry staining showed upregulation of Hsp70 in groups $\mathbf{C}-\mathbf{E}$. (A) and (B) are presenting the normal control and lesion control groups, respectively. The yellow arrow shows Hsp70 accumulation in gastric tissue (20x).

Abbreviation: EEAM, ethyl acetate extract of Annona muricata leaves.

\section{Conclusion}

The results obtained in this study showed the safety of EEAM in rats, even at the highest dose of $2 \mathrm{~g} / \mathrm{kg}$. However, further chronic toxicity testing should be conducted to confirm its safe usage. In vivo study in rats demonstrated the promising antiulcer effect of EEAM against gastric mucosal injury induced by ethanol. EEAM mediated its antiulcer potential probably through its ROS-scavenging activity and protective effect against GWM damage. In addition, Hsp70 upregulation and Bax downregulation were found to be involved in the suppression of gastric injuries. However, an investigation on the major active compound in EEAM is still required, to fully illustrate the antiulcer potential of Annona muricata leaves.
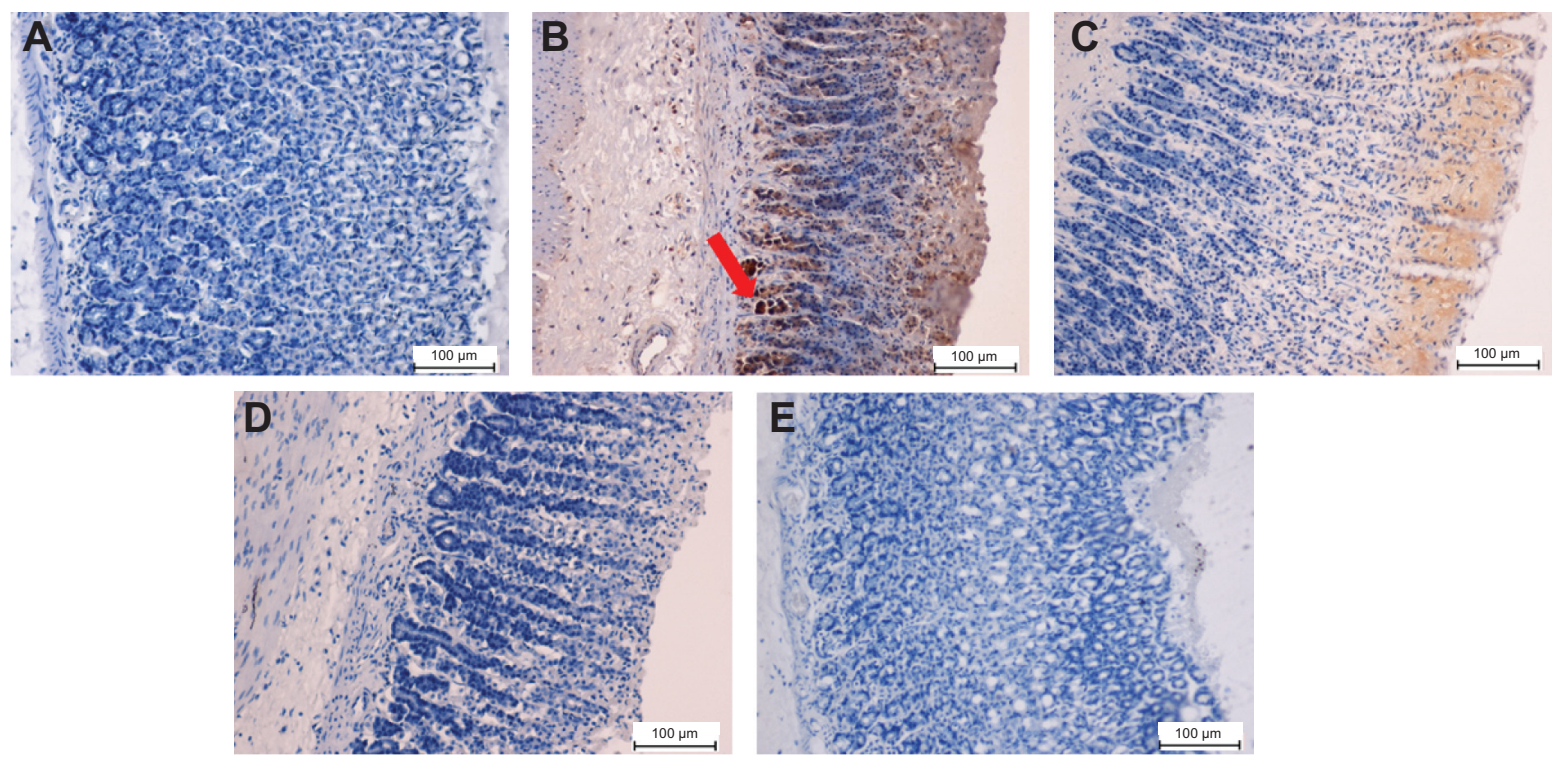

Figure 8 Immunohistochemical analysis of Bax protein expression from five groups of rats, namely: (A) normal control, (B) lesion control, (C) low dose of EEAM, (D) high dose of EEAM, and (E) omeprazole control. Immunohistochemistry staining showed downregulation of Bax in groups $\mathbf{C}-\mathbf{E}$. (A) and (B) are presenting the normal control and lesion control groups, respectively. The red arrow shows Bax protein accumulation in gastric tissue (20x).

Abbreviation: EEAM, ethyl acetate extract of Annona muricata leaves. 


\section{Acknowledgments}

This research was supported by the University of Malaya High Impact Research Chancellery (UM.C/625/1/HIR/175), University of Malaya Research Grant (RP001-2012C), and Postgraduate Research Fund (PG118-2013A).

\section{Disclosure}

The authors report no conflicts of interest in this work.

\section{References}

1. Zelickson MS, Bronder CM, Johnson BL, et al. Helicobacter pylori is not the predominant etiology for peptic ulcers requiring operation. $\mathrm{Am}$ Surg. 2011;77(8):1054-1060.

2. Thorsen K, Søreide JA, Kvaløy JT, Glomsaker T, Søreide K. Epidemiology of perforated peptic ulcer: age- and gender-adjusted analysis of incidence and mortality. World J Gastroenterol. 2013;19(3):347-354.

3. Ribeiro AR, Diniz PB, Estevam CS, Pinheiro MS, Albuquerque-Júnior RL, Thomazzi SM. Gastroprotective activity of the ethanol extract from the inner bark of Caesalpinia pyramidalis in rats. $J$ Ethnopharmacol. 2013;147(2):383-388.

4. Ramakrishnan K, Salinas RC. Peptic ulcer disease. Am Fam Physician. 2007;76(7):1005-1012.

5. Bertleff MJ, Lange JF. Perforated peptic ulcer disease: a review of history and treatment. Dig Surg. 2010;27(3):161-169.

6. Svanes C. Trends in perforated peptic ulcer: incidence, etiology, treatment, and prognosis. World J Surg. 2000;24(3):277-283.

7. Møller MH, Adamsen S, Wøjdemann M, Møller AM. Perforated peptic ulcer: how to improve outcome? Scand J Gastroentero. 2009;44(1): $15-22$.

8. Kobayashi M, Takeuchi M, Hashimoto S, et al. Contributing factors to gastric ulcer healing after endoscopic submucosal dissection including the promoting effect of rebamipide. Dig Dis Sci. 2012;57(1): 119-126.

9. Moriya M, Uehara A, Okumura T, Miyamoto M, Kohgo Y. Stressinduced hemorrhagic gastric ulcer after successful Helicobacter pylori eradication: two case reports. J Med Case Rep. 2011;5:252.

10. Andersen IB, Jørgensen T, Bonnevie O, Grønbaek M, Sørensen TI. Smoking and alcohol intake as risk factors for bleeding and perforated peptic ulcers: a population-based cohort study. Epidemiology. 2000; 11(4):434-439.

11. Bighetti AE, Antonio MA, Kohn LK, et al. Antiulcerogenic activity of a crude hydroalcoholic extract and coumarin isolated from Mikania laevigata Schultz Bip. Phytomedicine. 2005;12(1-2):72-77.

12. Lakshmi V, Singh N, Shrivastva S, et al. Gedunin and Photogedunin of Xylocarpus granatum show significant anti-secretory effects and protect the gastric mucosa of peptic ulcer in rats. Phytomedicine. 2010; 17(8-9):569-574.

13. Hajrezaie M, Hassandarvish P, Moghadamtousi SZ, et al. Chemopreventive evaluation of a Schiff base derived copper (II) complex against azoxymethane-Induced colorectal cancer in rats. PloS one. 2014;9(3): e91246.

14. Liu W, Chen Y, Lu G, Sun L, Si J. Down-regulation of HSP70 sensitizes gastric epithelial cells to apoptosis and growth retardation triggered by H. pylori. BMC Gastroenterol. 2011;11:146.

15. Otaka M, Odashima M, Watanabe S. Role of heat shock proteins (molecular chaperones) in intestinal mucosal protection. Biochem Biophys Res Commun. 2006;348(1):1-5.

16. Konturek PC, Brzozowski T, Ptak A, et al. Nitric oxide releasing aspirin protects the gastric mucosa against stress and promotes healing of stress-induced gastric mucosal damage: role of heat shock protein 70 . Digestion. 2002;66(3):160-172.

17. Basu S, Srivastava PK. Heat shock proteins: the fountainhead of innate and adaptive immune responses. Cell Stress Chaperon. 2000;5(5):443.
18. Mayer MP, Bukau B. Hsp70 chaperones: cellular functions and molecular mechanism. Cell Mol Life Sci. 2005;62(6):670-684.

19. Oyake J, Otaka M, Matsuhashi T, et al. Over-expression of 70-kDa heat shock protein confers protection against monochloramine-induced gastric mucosal cell injury. Life Sci. 2006;79(3):300-305.

20. Hirata I, Naito Y, Handa O, et al. Heat-shock protein 70-overexpressing gastric epithelial cells are resistant to indomethacin-induced apoptosis. Digestion. 2009;79(4):243-250.

21. Odashima M, Otaka M, Matsuhashi T, et al. Mechanical strain stress suppresses expression of HSP70 and wound restoration in gastric mucosal cells. Dig Dis Sci. 2007;52(11):3087-3091.

22. George VC, Kumar DR, Rajkumar V, Suresh PA, Kumar RA. Quantitative assessment of the relative antineoplastic potential of the n-butanolic leaf extract of Annona muricata Linn. in normal and immortalized human cell lines. Asian Pac J Cancer Prev. 2012;13(2): 699-704.

23. George VC, Kumar DR, Suresh PK, Kumar RA. Antioxidant, DNA protective efficacy and HPLC analysis of Annona muricata (soursop) extracts. J Food Sci Tech. 2014:1-8.

24. Zeng L, Wu FE, Oberlies NH, McLaughlin JL, Sastrodihadjo S. Five new monotetrahydrofuran ring acetogenins from the leaves of Annona muricata. J Nat Prod. 1996;59(11):1035-1042.

25. Gleye C, Laurens A, Hocquemiller R, Cavé A, Laprévote O, Serani L. Isolation of montecristin, a key metabolite in biogenesis of acetogenins from Annona muricata and its structure elucidation by using tandem mass spectrometry. J Org Chem. 1997;62(3):510-513.

26. Adewole SO, Caxton-Martins EA. Morphological changes and hypoglycemic effects of Annona muricata linn. (annonaceae) leaf aqueous extract on pancreatic $\beta$-cells of streptozotocin-treated diabetic rats. Afr J Biomed Res. 2006;9(3):173-180.

27. Adewole SO, Ojewole JA. Protective effects of Annona muricata Linn. (Annonaceae) leaf aqueous extract on serum lipid profiles and oxidative stress in hepatocytes of streptozotocin-treated diabetic rats. Afr J Tradit, Complement Altern Med. 2008;6(1):30-31.

28. Baskar R, Rajeswari V, Kumar TS. In vitro antioxidant studies in leaves of Annona species. Indian J Exp Biol. 2007;45(5):480.

29. Foong CP, Hamid RA. Evaluation of anti-inflammatory activities of ethanolic extract of Annona muricata leaves. Rev Bras Farmacogn. 2012; 22(6):1301-1307.

30. Karimian H, Mohan S, Moghadamtousi SZ, et al. Tanacetum polycephalum (L.) Schultz-Bip. induces mitochondrial-mediated apoptosis and inhibits migration and invasion in MCF7 cells. Molecules. 2014;19(7):9478-9501.

31. Robert A, Nezamis JE, Lancaster C, Hanchar A. Cytoprotection by prostaglandins in rats. Prevention of gastric necrosis produced by alcohol, $\mathrm{HCl}, \mathrm{NaOH}$, hypertonic $\mathrm{NaCl}$, and thermal injury. Gastroenterology. 1979;77(3):433-443.

32. Gamberini MT, Skorupa LA, Souccar C, Lapa AJ. Inhibition of gastric secretion by a water extract from Baccharis triptera, Mart. Mem Inst Oswaldo Cruz. 1991;86 Supp1 2:137-139.

33. Corne SJ, Morrissey SM, Woods RJ. Proceedings: A method for the quantitative estimation of gastric barrier mucus. J Physiol. 1974; 242(2):116P-117P.

34. Hajrezaie M, Golbabapour S, Hassandarvish P, et al. Acute toxicity and gastroprotection studies of a new schiff base derived copper (II) complex against ethanol-induced acute gastric lesions in rats. PloS one. 2012; 7(12):e51537.

35. Golbabapour S, Gwaram NS, Hassandarvish P, et al. Gastroprotection studies of Schiff base zinc (II) derivative complex against acute superficial hemorrhagic mucosal lesions in rats. PloS one. 2013;8(9): e75036.

36. Moghadamtousi SZ, Kamarudin MN, Chan CK, Goh BH, Kadir HA. Phytochemistry and biology of Loranthus parasiticus Merr, a commonly used herbal medicine. Am J Chin Med. 2014;42(1):23-35.

37. Falcão HS, Mariath IR, Diniz MF, Batista LM, Barbosa-Filho JM. Plants of the American continent with antiulcer activity. Phytomedicine. 2008;15(1-2):132-146. 
38. Awaad AS, El-Meligy RM, Soliman GA. Natural products in treatment of ulcerative colitis and peptic ulcer. J Saudi Chem Soc. 2013;17(1): 101-124.

39. Yadav DK, Singh N, Dev K, et al. Anti-ulcer constituents of Annona squamosa twigs. Fitoterapia. 2011;82(4):666-675.

40. Chilaka KC, Unekwe PC, Chilaka JU, Nweke IN. Studies on the antiulcer properties of ethanolic leaf extracts of Uvaria chamae. Trop $J$ Med Res. 2010;14(2).

41. Chanda S, Baravalia Y, Kaneria M. Protective effect of Polyalthia longifolia var. pendula leaves on ethanol and ethanol/ $\mathrm{HCl}$ induced ulcer in rats and its antimicrobial potency. Asian Pac J Trop Med. 2011; 4(9):673-679.

42. Sharma RK, Mandal S, Rajani GP, Gupta N, Srivastava DP. Antiulcer and antiinflammatory activity of fresh leave extracts of Polyalthia longifolia in rats. Int J Drug Dev Res. 2011;3:351-359.

43. Pélissier Y, Marion C, Kone D, Lamaty G, Menut C, Bessière J-M. Volatile components of Annona muricata L. J Essent Oil Res. 1994;6(4): 411-414.

44. Kossouoh C, Moudachirou M, Adjakidje V, Chalchat J-C, Figuérédo G. Essential oil chemical composition of Annona muricata L. leaves from Benin. J Essent Oil Res. 2007;19(4):307-309.

45. Calleja MA, Vieites JM, Montero-Meterdez T, et al. The antioxidant effect of $\beta$-caryophyllene protects rat liver from carbon tetrachlorideinduced fibrosis by inhibiting hepatic stellate cell activation. Br J Nutr. 2013;109(3):394-401.

46. Costa EV, Dutra LM, de Jesus HC, et al. Chemical composition and antioxidant, antimicrobial, and larvicidal activities of the essential oils of Annona salzmannii and A. pickelii (Annonaceae). Nat Prod Commun. 2011;6(6):907-912.

47. Thang TD, Dai DN, Hoi TM, Ogunwande IA. Study on the volatile oil contents of Annona glabra L., Annona squamosa L., Annona muricata L. and Annona reticulata L., from Vietnam. Nat Prod Res. 2013; 27(13):1232-1236.

48. Chavan MJ, Wakte PS, Shinde DB. Analgesic and anti-inflammatory activity of Caryophyllene oxide from Annona squamosa L. bark. Phytomedicine. 2010;17(2):149-151.

49. Déciga-Campos M, Rivero-Cruz I, Arriaga-Alba M, et al. Acute toxicity and mutagenic activity of Mexican plants used in traditional medicine. J Ethnopharmacol. 2007;110(2):334-342.

50. de Sousa OV, Vieira GD, de Jesus RG, Yamamoto CH, Alves MS. Antinociceptive and anti-inflammatory activities of the ethanol extract of Annona muricata L. leaves in animal models. Int J Mol Sci. 2010;11(5):2067-2078.

51. Li XQ, Andersson TB, Ahlström M, Weidolf L. Comparison of inhibitory effects of the proton pump-inhibiting drugs omeprazole, esomeprazole, lansoprazole, pantoprazole, and rabeprazole on human cytochrome P450 activities. Drug Metab Dispos. 2004;32(8):821-827.

52. Schneeweiss S, Maclure M, Dormuth CR, Glynn RJ, Canning C, Avorn J. A therapeutic substitution policy for proton pump inhibitors: clinical and economic consequences. Clin Pharmacol Ther. 2006;79(4): 379-388.

53. Tang RS, Wu JC. Managing peptic ulcer and gastroesophageal reflux disease in elderly Chinese patients - focus on esomeprazole. Clin Interv Aging. 2013;8:1433-1443.

54. Borrelli F, Izzo AA. The plant kingdom as a source of anti-ulcer remedies. Phytother Res. 2000;14(8):581-591.

55. Brzozowski T, Konturek PC, Konturek SJ, et al. Role of gastric acid secretion in progression of acute gastric erosions induced by ischemia-reperfusion into gastric ulcers. Eur J Pharmacol. 2000;398(1): $147-158$.

56. Masuda Y, Tanaka T, Inomata N, et al. Ghrelin stimulates gastric acid secretion and motility in rats. Biochem Biophys Res Commun. 2000; 276(3):905-908

57. Laloo D, Prasad SK, Krishnamurthy S, Hemalatha S. Gastroprotective activity of ethanolic root extract of Potentilla fulgens Wall. ex Hook. J Ethnopharmacol. 2013;146(2):505-514.
58. Wallace JL. Nonsteroidal anti-inflammatory drugs and the gastrointestinal tract. Mechanisms of protection and healing: current knowledge and future research. Am J Med. 2001;110(1A):19S-23S.

59. Kwiecien S, Brzozowski T, Konturek SJ. Effects of reactive oxygen species action on gastric mucosa in various models of mucosal injury. J Physiol Pharmacol. 2002;53(1):39-50.

60. Avci E, Akarslan ZZ, Erten H, Coskun-Cevher S. Oxidative stress and cellular immunity in patients with recurrent aphthous ulcers. Braz J Med Biol Res. 2014;47(5):355-360.

61. Rozza AL, de Mello Moraes T, Kushima H, Nunes DS, Hiruma-Lima CA, Pellizzon $\mathrm{CH}$. Involvement of glutathione, sulfhydryl compounds, nitric oxide, vasoactive intestinal peptide, and heat-shock protein-70 in the gastroprotective mechanism of Croton cajucara Benth. (Euphorbiaceae) essential oil. J Med Food. 2011;14(9):1011-1017.

62. Oliveira FA, Vieira-Júnior GM, Chaves MH, et al. Gastroprotective and anti-inflammatory effects of resin from Protium heptaphyllum in mice and rats. Pharmacol Res. 2004;49(2):105-111.

63. Pan LR, Tang Q, Fu Q, Hu BR, Xiang JZ, Qian JQ. Roles of nitric oxide in protective effect of berberine in ethanol-induced gastric ulcer mice. Acta Pharmacol Sin. 2005;26(11):1334-1338.

64. Tuchinda P, Reutrakul V, Claeson P, et al. Anti-inflammatory cyclohexenyl chalcone derivatives in Boesenbergia pandurata. Phytochemistry. 2002;59(2):169-173.

65. Kobayashi T, Ohta Y, Yoshino J, Nakazawa S. Teprenone promotes the healing of acetic acid-induced chronic gastric ulcers in rats by inhibiting neutrophil infiltration and lipid peroxidation in ulcerated gastric tissues. Pharmacol Res. 2001;43(1):23-30.

66. Demircan B, Çelik G, Süleyman H, Akçay F. Effects of indomethacin, celecoxib and meloxicam on glutathione, malondialdehyde and myeloperoxidase in rat gastric tissue. Pain Clinic. 2005;17(4): 383-388.

67. Kasdallah-Grissa A, Mornagui B, Aouani E, et al. Resveratrol, a red wine polyphenol, attenuates ethanol-induced oxidative stress in rat liver. Life Sci. 2007;80(11):1033-1039.

68. Konturek SJ, Konturek PC, Brzozowski T. Prostaglandins and ulcer healing. J Physiol Pharmacol. 2005;56 Suppl 5:5-31.

69. Hatazawa R, Tanaka A, Tanigami M, et al. Cyclooxygenase-2/prostaglandin E2 accelerates the healing of gastric ulcers via EP4 receptors. Am J Physiol Gastrointest Liver Physiol. 2007;293(4):G788-G797.

70. Sakata D, Yao C, Narumiya S. Prostaglandin E2, an immunoactivator. J Pharmacol Sci. 2010;112(1):1-5.

71. Ngosuwan J, Wang NM, Fung KL, Chirico WJ. Roles of cytosolic Hsp70 and Hsp40 molecular chaperones in post-translational translocation of presecretory proteins into the endoplasmic reticulum. $J$ Biol Chem. 2003;278(9):7034-7042.

72. Santoro MG. Heat shock factors and the control of the stress response. Biochem Pharmacol. 2000;59(1):55-63.

73. Mosser DD, Caron AW, Bourget L, et al. The chaperone function of hsp70 is required for protection against stress-induced apoptosis. Mol Cell Biol. 2000;20(19):7146-7159.

74. Suemasu S, Tanaka K, Namba T, et al. A role for HSP70 in protecting against indomethacin-induced gastric lesions. J Biol Chem. 2009; 284(29):19705-19715.

75. Elmore S. Apoptosis: a review of programmed cell death. Toxicol Pathol. 2007;35(4):495-516.

76. Qiao WL, Wang GM, Shi Y, et al. Differential expression of Bcl-2 and Bax during gastric ischemia-reperfusion of rats. World J Gastroenterol. 2011;17(13):1718-1724.

77. Ocker M, Höpfner M. Apoptosis-modulating drugs for improved cancer therapy. Eur Surg Res. 2012;48(3):111-120.

78. Mahr S, Neumayer N, Gerhard M, Classen M, Prinz C. IL-1betainduced apoptosis in rat gastric enterochromaffin-like cells is mediated by iNOS, NF-kappaB, and Bax protein. Gastroenterology. 2000;118(3):515-524. 
Drug Design, Development and Therapy

Dovepress

\section{Publish your work in this journal}

Drug Design, Development and Therapy is an international, peerreviewed open-access journal that spans the spectrum of drug design and development through to clinical applications. Clinical outcomes, patient safety, and programs for the development and effective, safe, and sustained use of medicines are a feature of the journal, which

has also been accepted for indexing on PubMed Central. The manuscript management system is completely online and includes a very quick and fair peer-review system, which is all easy to use. Visit http://www.dovepress.com/testimonials.php to read real quotes from published authors.

Submit your manuscript here: http://www.dovepress.com/drug-design-development-and-therapy-journal 